\title{
Factions as Social Classes in Divergent novel by Veronica Roth (Marxism Study)
}

\author{
Hosmawati ${ }^{1}$, Endang Suciati ${ }^{2}$ \\ ${ }^{1}$ Universitas Pesantren Tinggi Darul Ulum \\ hosmawati@gmail.com \\ ${ }^{2}$ Universitas Pesantren Tinggi Darul Ulum \\ endangsuciati@fbs.unipdu.ac.id
}

\begin{abstract}
Divergent novel tells the story about human factions community. Since this novel discussed about the domination of factions in the novel as delineation in social class or social life and struggle of the factions in society, this novel was analyzed using Marxism theory. The method used was descriptive qualitative to explain the kinds of factions and the struggles of the factions considered as social classes to get the power in society. Thus, this novel was analyzed using the theory Marxism which focused on the kinds of factions the struggles the factions done. The data were in the form of utterances in Divergent novel written by veronica Roth. The result of the research showed that factions in the novel depicted the social class in society as there are powerless and powerful faction group.They are categorized as bourgeois or capitalism and proletarian. Therefore, the researcher classified the events in the novel related to factions which were similar to social classes. The faction of Abnegation and Erudite are the same as the bourgeois or capitalism because they often oppress the weak and always want to control all factions with the wealth and power they have. On the other hand, Dauntless, Amity and Candor are the same as the proletarian because they are oppressed factions which have no power in society. The factions did some efforts or struggles to maintain or to get the power in society. It can be concluded that this novel uncovered the life of social class which was represented by faction and the struggles done in terms of getting the power and surviving the life.
\end{abstract}

Keywords: marxism, social class, faction, Divergent

\begin{abstract}
Abstrak
Novel Divergent bercerita tentang faksi dalam masyarakat. Karena novel banyak membahas tentang faksi sebagai gambaran dalam suatu kelas sosial atau kehidupan sosial dan perjuangan masing-masing faksi dalam masyarakat, maka novel ini dianalisis menggunakan teori Marxisme. Metode yang digunakan adalah deskriptif kualitatif untuk menjelaskan jenis-jenis faksi dan perjuangan faksi-faksi yang dianggap sebagai kelas sosial untuk mendapatkan kekuasaan dalam masyarakat. Dengan demikian, novel ini dianalisis menggunakan teori Marxisme yang fokus pada jenis-jenis faksi dan perjuangan yang dilakukan. Data penelitian berupa pernyataan/ujaran dalam novel Divergent yang ditulis oleh veronica Roth. Hasil penelitian menunjukkan bahwa faksi-faksi dalam novel tersebut menggambarkan kelas sosial dalam masyarakat karena ada kelompok faksi yang lemah dan kuat. Mereka dikategorikan sebagai borjuis atau kapitalisme dan proletar. Oleh karena itu, peneliti mengklasifikasikan peristiwa-peristiwa dalam novel yang berkaitan dengan faksi-faksi yang mirip dengan kelas-kelas sosial. Faksi Abnegation dan Erudite memiliki kesamaan dengan borjuis atau kapitalisme karena mereka sering menindas yang lemah dan
\end{abstract}


selalu ingin mengendalikan semua faksi dengan kekayaan dan kekusaanyang dimiliki. Di sisi lain, Dauntless, Amity and Candor sama dengan proletar karena mereka adalah faksi tertindas yang tidak memiliki kekuasaan dan kekuatan dalam masyarakat. Faksi-faksi melakukan beberapa upaya atau perjuangan untuk mempertahankan atau mendapatkan kekuasaan di masyarakat. Dapat disimpulkan bahwa novel ini mengungkap kehidupan kelas sosial yang diwakili oleh faksi dan perjuangan yang dilakukan dalam hal mendapatkan kekuasaan dan bertahan hidup.

Kata kunci: marxisme, kelas social, faksi, Divergent

\section{INTRODUCTION}

Divergent novel was written by Veronica Roth. She is a US smart author who is famous for her trilogy novel, entitled Divergent, Insurgent and Allegiant. Divergent novel is one of the trilogy novels which published in 2011. According to Elmira primananda (2015: 2), the novel got an award as New York bestseller winning novel and also New York Times Bestseller directly in the same year in 2011 and Good Reads Favorite Books of 2011 and the Best Young Adult and Science Fiction.

Beside its popularity, the content of the novel becomes another thing that makes this novel is interesting to be analyzed. Divergent novel explains about how a community life in different faction which lately is considered as social class is described. Related to the real life, faction is close to social class since it has its own group based on certain criteria like ownership, economy, power, etc. In general, social class is divided into two groups which is related to Marxism theory by Karl Marx (1989), those are bourgeois or capitalists and proletariat. It can be said also that social class is the class division in society based on specific criteria, whether by religion, education, economic status, descent and etc. Philip N. Cohen said "Social class is a status in which individuals and groups are classified on the basis of esteem and prestige acquired mainly through economic success and accumulation of wealth. (2007: 18). As we can see in the example quotation from the novel that one of the factions, abnegation, which is very dominant in terms of power in society.

"Marcus is my father's coworker. They are both political leaders. The city is ruled by a council of fifty people, composed entirely of representatives from abnegation, because our faction is regarded as incorruptible, due to our commitment to selflessness. "(Roth, 2011: 44).

The quotation proves that Abnegation, as the faction owned by Marcus, has power to be a leader, and the faction is very strong until it is regarded as "incorruptible". However, the way this faction used is "selflessness". This characteristic is close to bourgeois or 
capitalist criteria in society because bourgeois or capitalist is rich and has power. Thus, this group can do whatever they want to do.

Marx sees capitalism as a system that has many weaknesses. According to Marx, capitalism is a form of exploitation on labor. Capitalism keeps the workers alienated or alienates. This forces the workers to be isolated and unable to grow. Labor is used as a means or tool to meet the needs of the capitalists. In other words, labor is alienated from its basic nature as a human being (Ritzer, Goodman, 2011: 36). Based on the novel, some factions considered as labor or alienatedsothey belong to proletar. Karl Marx in the German Ideology and The Communist Manifesto written in London with Friederich Engels (1872) proletar showed that economic competition is the engine of capitalism will encourage capitalism to replace labor with machines.

Related to the description above, this research analyzed Veronica Roth's Divergent using Marxism theory by Karl Marx (1989) since the novel mainly talks about faction which is close to social class including the struggles done by the factions to get the power in society.

\section{RESEARCH ETHOD}

This research is descriptive qualitative method since the data are not in form of numbers and it really needs further description and explanation from the researcher's point of view based on the theory. The data analyzed were utterances in Divergent novel by Veronica Roth. The source of data is a novel entitled "Divergent" by Veronica Roth which published by Harper Collins Publishers in 2011, in Chicago United States of America, first edition from trilogy novels. It has 543 pages and 39 chapters. This research figured out the analysis related to social class using Karl Marx's theory by some steps starting from identifying factions that considered as social class in Divergent novel By Veronica Roth, explaining the struggles of faction as the social class to get the power in society in the novel and deriving conclusion.

\section{FINDING AND DISCUSSION}

This part explained the kinds of factions considered as social classes in Divergent novel and how they struggle to get the power in society. It would be described through the theory of Marxism by Karl Marx. The factions which are considered as social class found in the novel are five. They are Abnegation, Erudite, Dauntless, Amity and Candor.

\subsection{Factions in Divergent novel}


In Divergent novel, Veronica Roth described factions as social class. There were many kinds of factions with their characteristics that had similar characteristics to those of social classes. As it is stated in the quotation below:

The amity exchange smiles. They are dressed comfortably, in red or yellow. Every time I see them, they seem kind, loving, and free. But joining them has never been an option for me. "Those who blamed ignorance became the Erudite." Ruling out Erudite was the only part of my choice that was easy. "Those who blamed duplicity created Candor. "I have never liked Candor. "Those who blamed selfishness made Abnegation. "I blame selfishness; I do. "And those who blamed cowardice were the Dauntless. (Roth, 2011: 41)

The quotation above explained that there were five factions. They were Abnegation. Erudite, Dauntless, Candor and Amity. Amity were group of people with good looking by the thing they wear "dressed comfortably, in red or yellow" and full of affection "Every time I see them, they seem kind, loving, and free". Erudite was group of people who had a good ability in science. Furthermore, they were intelligent people. Candor never told a lie always honest. Abnegation was be selfish and Dauntless was brave in fighting and they hated cowardice. People had to choose one of these factions because they cannot live without having self-identity.

\subsubsection{Abnegation and Erudite as Bourgeois or Capitalist}

Abnegation and Erudite factions were the Bourgeois factions in the Divergent novel because they had the power to conquer other factions. Both Abnegation and Erudite belong to bourgeois social class because they liked to oppress group of weak people and warlike because they want to dominate all factions. It can be seen in the quotation below:

But it has strayed far from them. And the same Erudite, I realize. A long time ago, Erudite pursued knowledge and ingenuity for the sake of doing well. Now they pursue knowledge and ingenuity with greedy hearts. I wonder if the other factions suffer from the same problem. I have not thought about it before. (Roth, 2011: 161)

The word "them" in the quotation means Abnegation and has something similar to Erudite " And the same Erudite ". The quotation above explained that Erudite pursued science and intelligence to oppress and dominated the other factions "pursued knowledge and ingenuity for the sake of doing well". Their intelligence was used to fight. However they used it in a bad way "with greedy hearts" in this case the greedy heart is used to oppress other faction thus there is a fear to have a problem nextbetween these factionin society. It seems that thisfaction is dominant faction. These characteristics were close to those of bourgeois since Abnegation, Erudite and bourgeois can be assumed as a faction who are 
hungry of being the domination and wanted to conquer the lower groups. On the other occasion, Erudite always oppressed the weak and invited war by some cunning ways even though they were often defeated in battle. They led by a woman named Jeanine Matthews. This statement supported by the quotation below:

"It this about the report Jeanine Matthews released?" my mother says. Jeanine Matthews is Erudite sole representative, selected based on IQ score. My father complains about her often. (Roth, 2011: 33)

The quotation above explained the Erudite faction led by a woman named Jeanine Matthews who has the highest IQ in the faction and very cunning in leading the faction although Jeanine had exceptional intelligence. Therefore, Jeanine Matthews was categorized as bourgeois since she had sly characteristic and liked to oppress the weak.

The high IQ possessed by Jeanine Matthew was only used for the selfishness of Janine Matthew in the Erudite faction, high IQ was usually mostly owned by educated people and rich people because rich people were able go to school and had a lot of money. Education was very important for the Erudite faction because educated people will cause a person to be rich and successful. But different from Janine Matthew, she used her intelligence to oppress the weak and never helped the poor as the characteristics of the bourgeois they always oppress the weak with their riches.

\subsubsection{Dauntless, Candor and Amity as proletar}

Dauntless, Candor and Amity were the factions that considered as low faction in Divergent novel as they were the factions that all the member work as farmers. They loved to live peacefully and did not have the capital or lots of money to buy and to do something. They belonged to proletar social class. They worked for the bourgeois to earn salary but their salary was low.

Four leads us toward the gate, which is as a house and opens up to the cracked road the leads to the city. When I came here with my family as child, we rode in a bus on that road and beyond, to amity's farms, where we spent the day picking tomatoes and sweating through our shirts.(Roth, 2011: 101)

The quotation above explained that amity that lived in a simple house and poor city or village by the road described "a house and opens up to the cracked road the leads to the city". It indicates that they are not rich people. They worked as farmers or even a labor since they spent the day for "picking tomatoes and sweating through their shirts". They were forced to work hard in farming lands. In the quotation, someone that explained as the one whose 
family comes from an Amity faction. Being a farmer is also the job of candor faction. They work for abnegation faction. They work hard but they only got in salary with low wages. Working as a farmer is one of the jobs of the proletariat although they were sometimes not get the salary but they worked really hard.

Meanwhile, Dauntless faction identified as proletarian social class as they did some works that was asked by Erudite faction, even though Erudite were brave in war and struggled against challenges, in this position Dauntless was just wielded by Erudite faction. It is showed by the quotation below:

I have realized that part of being Dauntless is being willing to make things more difficult for yourself in order to be self-sufficient. There's nothing especially brave about wandering dark streets with no flashlight, but we are not supposed to need help, even from light, we are supposed to be capable of anything. I like that. Because there might come a day when there is no flashlight, there is no guiding hand. And I want to be ready for it. (Roth, 2011: 112)

The quotation showed that Dauntless factions should be brave in battle even though they were fighting without weapons and any assistance and even without light. They should be able to fight against the enemy and they should able to prepare to face it, because a brave man does not need anything even a flashlight and any light. Dauntless factions belong to proletarian class since dauntless are helpful. Their courage in battle used to help people who need it, because abnegation liked to help the other people.

\subsection{Struggles of the Factions}

These factions which were considered as social class also didsome efforts or struggle dealing with their life among factions aspecially in getting the power in society. In this part, there are explanations about struggles of faction as social class. All Factions must be able to survive and fight for the existence in society. In Divergent novel, there were five factions and they must struggle their life in society. As it stated in the quotation below:

"I can control what you see and hear," she says. "So I created a new serum that will adjust your surroundings to manipulate your will. Those who refuse to accept our leadership must be closely monitored."Monitored- or robbed of free will. She has a gift with words. "You will be the first test subject, Tobias. Beatrice, however "she smiles. "You are too injured to be of much this meeting." (Roth, 2011: 335)

"I" in the quotation above is Erudite faction who really want to control another faction by creating aninovation, a serum. It is explained that Erudite creates serums which were purposed to manipulate all factions and master all factions. Janine was the one who created 
the serum.Her intelligence was used for bad things because erudite were thirsty of power. Therefore, erudite faction created the serum in order to be able to control brain and mind of all factions and oppress the weak. Tobias and Beatrice wanted to destroy the serum because it was very dangerous for the other factions.

The intelligence of the erudite faction got because they have a lot of money and capital, they can create serums and buy computers, so they can master all the factions. The character of erudite is the same as the bourgeois who want to control all factions by using money. Money is one of the economic side where certain faction is different from.

Another quotation showed that certain faction did an effort in surviving theirlife. Factions must be able to fight for their life even though they will eventually die. It was described well in the quotation bellow:

My mother stiffens, her back arching, blood surges from a wound in her abdomen, dyeing her shirt crimson. A patch of blood spreads over her shoulder. I blink, and the violent red stains the inside of my eyelids. I blink again, and I see her smile as she sweeps my hair trimmings into a pile. I clamp my hand over my mouth and scream into my palm. My cheeks are hot and wet with tears I didn't feel beginning. My blood cries out that it belongs to her, and struggles to return to her, and I hear her words in my mind as I run, telling me to be brave. (Roth, 2011: 343)

From the quotation above, everyone ran quickly because the Erudite faction was successful manipulate the Dauntless faction, all people were frightened and tried to save themselves. Beatrice and her mother were trying to save themselves from the Dauntless attack, but Beatrice's mother was no longer had the strength to run because she had been shot in the stomach, the blood came out from her stomach and she could not bear the sick any longer. This hurt was not an excuses to fight agints the other faction. Although Dauntless faction was oppressed, no power, they encourage theirselves by braveness. Nothing in materials, as the proletar had, but they still have spirit, as the struggle among the factions to be survived although finally they were still weak and hurt.

\section{CONCLUSION}

Based on the analysis, Divergent novel discussed about five kinds of factions (Abnegation, Erudite, Dauntless, Amity and Candor). Each faction has its unique and different characters. Its way of life was close to the life of social class in a society. It was found that there were two groups of social class whose members were that is Abnegation and Erudite same as bourgeois and Dauntless, Amity and Candor same as proletar. These 
two groups tried to get the power in society by trying to control all factions or suppressing weak factions because one faction has an evil plan to master all factions.

The effort of Abnegation and Erudite finally did not give good benefits. All factions were chaotic as there was a war among all factions that lead to the point to kill factions who wanted to dominate the war. Finally, Abnegation and Erudite factions that caused the war had defeated and there is no advantage in suppressing all factions.

This shows that factions which are considered as social classes are competing to get the power. It is not only for the strong class division to maintain the power but also the weak division to survive the life.

\section{REFERENCES}

Frederich and Engels. 1848. The Communist Manifesto, Melbourne: Melbourne Scholl of Continental Phylosophy.

Marx, K. (1995, 2002:106) "Beginning Theory an Introduction to Literary and Cultural Theory Second Edition Peter Barry.

Marx, K. (1872) in the German Ideology and the Communist Manifesto. London.

Oxford Advanced Learner's Dictionary.

Primananda, E. 2015 "Analyzing Hegemony Faction System in Veronica Roth's

Philip N. Cohen, 2007. World Book Encyclopediasocila. London

Roth, V. (2011)” Divergent".Bandung: PT Mizan Pustaka

Roth, V. Divergent. New York: Harper Collins, 2011. 